\title{
A ciência na mídia e as estratégias de reafirmação da bipolaridade entre os gêneros: o caso do Globo Repórter
}

\author{
Cláudia Regina Ribeiro** \\ Fabíola Rohden ${ }^{* * * *}$
}

\begin{abstract}
Resumo
A partir do estudo do programa Globo Repórter, este artigo discute as articulações percebidas na mídia entre natureza $e$ as questões de gênero. Selecionamos dois programas exibidos em semanas consecutivas que empreendem um grande esforço para explicar as diferenças de gênero e o amor materno a partir de noções essencialistas e do privilégio do corpo biológico, indo ao encontro do que as ciências médicas vêm se empenhando em defender na busca de descobertas de "verdades" sobre o tema, $e$ em detrimento dos aspectos sócio-culturais dessas construções.
\end{abstract}

Palavras-chave: Mídia, Corpo, Gênero, Ciência.

\footnotetext{
* Recebido para publicação em janeiro de 2008, aceito em julho de 2008.

** Doutoranda do Instituto de Medicina Social - IMS/UERJ. 13cribeiro@gmail.com

****Docente do Instituto de Medicina Social - IMS/UERJ. fabiola@ims.uerj.br
} 
A ciência na mídia

Science in the Media and Strategies to Reaffirm Gender Bipolarity between Genders: Globo Reporter Case Study

\begin{abstract}
From the study of Globo Repórter television program this article discusses the media articulations between nature and gender issues. We selected two editions, shown in consecutive weeks, which undertake great effort to explain the differences of gender and for maternal love, since essentialists notions and the privilege of the biologic body, in accordance with the efforts these medical sciences have been making in search of the "truth" about the issue, despite the social and cultural aspects of this construction.
\end{abstract}

Key Words: Media, Body, Gender, Science. 
Cláudia Ribeiro e Fabíola Rohden

\section{Introdução}

Veiculado em horário nobre pela Rede Globo de Televisão, o Programa Globo Repórter foi criado em 1973 "para suprir uma carência do público de se aprofundar no conhecimento de assuntos polêmicos ou de interesse geral", segundo informações em seu site. ${ }^{1}$ Trata-se de um programa da grade de jornalismo da emissora e, também de acordo com o site, é assistido hoje por cerca de 30 milhões de telespectadores/as. O programa nos interessa especialmente por inscrever-se no gênero jornalístico que, como destaca Rial (2007), tem sido vagamente abordado pelas pesquisas no que tange às representações de relações de gênero, diferentemente do que acontece com as telenovelas e a publicidade, por exemplo. Além disso, pertencendo a esse gênero, o programa tem grande credibilidade junto ao público e suas informações tendem a ser tomadas como neutras e verdadeiras.

Já há alguns anos o programa tem se dedicado a apresentar as chamadas bases científicas de inúmeras questões, inclusive das diferenças entre homens e mulheres, assim como tem ocorrido na mídia de um modo geral. Contudo, podemos sugerir que a insistência no tema da diferenciação dos gêneros via o ancoramento biológico tem se tornado cada vez mais freqüente $e$ enfática. Exemplo disso foi o que ocorreu no mês de maio de 2007 quando o tema foi levantado em dois programas consecutivos, o primeiro (04 de maio) como assunto principal e o segundo (11 de maio) que atuou, do nosso ponto de vista, como um reforço das abordagens defendidas no primeiro. Acreditamos que a proximidade temporal das edições analisadas neste artigo ajudou a projetar e manter o tema das diferenças sexuais, do binarismo entre os gêneros e da primazia das ciências biomédicas sobre essas questões em evidência junto ao público, conferindo ainda

1 www.globo.com/globoreporter 
A ciência na mídia

relevância e veracidade a eles ${ }^{2}$, tornando esses dois programas casos exemplares de como a mídia tem tratado essas questões. Para a análise tomaremos o primeiro programa como foco central e o segundo como elemento importante para o reforço dessas idéias.

Assim, apoiadas nas informações do site, podemos dizer que o programa de 04 de maio de 2007, intitulado "Um homem e uma mulher: as mais novas descobertas da ciência sobre as diferenças entre os sexos", visava informar ao público sobre a existência dessas diferenças. Enquanto o veiculado na semana seguinte, 11 de maio, intitulado "Amor materno: o Globo Repórter investiga o mais intenso de todos os afetos", procurou mostrar as bases biológicas desse amor e, embora não explicitamente, reforçou a idéia já trazida pelo programa anterior de binarismo entre os sexos.

Este artigo pretende analisar na mídia televisiva o que já temos observado na imprensa escrita, a partir de uma pesquisa acadêmica que investiga as representações de gênero $e$ as novas tecnologias da sexualidade, entre outros temas, nas revistas Veja e Época publicadas entre 1990 e 2007. ${ }^{3}$ Como resultados preliminares, destacamos a evidência de que as abordagens jornalísticas localizam nos hormônios e no cérebro as diferenças entre homens e mulheres, tomam esses aspectos para explicar comportamentos sexuais e questões de gênero, e reforçam o

2 Tomamos como argumento para essa afirmação a teoria de agendamento da mídia, ou Agenda Setting, que se inclui no contexto dos estudos sobre os efeitos dos meios de comunicação na sociedade. Trata-se de um tipo de efeito social deflagrado a partir da seleção, disposição, hierarquização e incidência de temas na mídia, conferindo importância às notícias e temas selecionados pelos meios de comunicação e sinalizando para o público sobre o que se deve falar e estar informado, negligenciando, em conseqüência, outros temas e abordagens (Brum, 2003; Barros Filho, 2001).

3 Novos discursos e normas em torno do sexo: saberes profissões e intervenções médico-farmacêuticas. Projeto de Pesquisa coordenado por Fabíola Rohden, apoiado pelo CNPq e desenvolvido no IMS-UERJ desde 2007, cujo tema central é a medicalização da sexualidade e as questões de gênero. 
Cláudia Ribeiro e Fabíola Rohden

binarismo a partir de uma abordagem biologicista. ${ }^{4}$ Como exemplos de reportagens que tratam especificamente das diferenças de gênero apenas no ano de 2007, podemos citar as matérias de capa "Enfim a ciência entendeu a mulher: uma revolução muda (quase) tudo na forma como a medicina trata o corpo feminino" (Veja, 07/03/2007) e "Ela nasceu com as conquistas do feminismo. É independente, mas precisa de um companheiro. E não se importa em ser admirada pela beleza. Ela é a Mulher Alfa" (Época, 26/03/2007). Entre as matérias de destaque nas revistas temos a exemplar "Como pensam as mulheres. Uma neuropsiquiatra aponta as razões biológicas que tornam o cérebro feminino diferente do masculino" (Época, 29/01/2007). Também nas revistas especializadas dedicadas à área científica temos visto que as diferenças entre os sexos estão em pauta. A revista Viver - Mente e Cérebro, em sua edição de março desse mesmo ano tem como título: "Diferenças entre os sexos: muito além dos fatores culturais, a diversidade entre homens $e$ mulheres é inata". Em outra edição especial da mesma revista (sem data), temos como título: "A trégua dos sexos. Bases neurais, cognitivas e hormonais determinam divergências e convergências entre homens e mulheres". Entre as matérias de jornais podemos destacar: "Trair é natural. Pesquisadores dizem que homens são polígamos por natureza e mulheres tampouco são fiéis. Para se adequarem à monogamia, criaram a fidelidade de fachada!" $(O$ Globo, Caderno Ciência, 19/08/2007).

No que se refere à mídia televisiva, os exemplos também têm sido cada vez mais freqüentes, como os destacados na

4 Classificamos da seguinte forma as 111 matérias e/ou notas encontradas na revista Veja entre os anos de 1990 e 2007 que tratavam dos temas da pesquisa: Medicamentalização da Disfunção Sexual Masculina (27); Medicamentalização da Disfunção Sexual Feminina (6), Hormônios/Terapia de Reposição Hormonal (14); Comportamento Sexual (41); Diferenças Biológicas entre Homens e Mulheres (5); Contraceptivos (11); Notas sobre drogas sexuais (7). Foram encontradas ainda 23 propagandas publicitárias sobre medicamentalização da disfunção sexual masculina. 
A ciência na mídia

programação da Rede Globo, emissora que veicula o Globo Repórter. Outra edição desse programa, veiculada em 02 de novembro de 2007, intitulada "Hormônios: mensageiros invisíveis. Saiba como eles comandam nossas vidas", destacou os efeitos dessas substâncias sobre os corpos como principais responsáveis sobre alguns comportamentos, inclusive das diferenças de gênero. Em outro exemplo da grade de programação da mesma emissora, a edição do Fantástico de 30 de setembro apresentou um quadro intitulado: "Quem é mais inteligente: o homem ou a mulher?", seguindo a mesma linha em que procurou ressaltar as qualidades femininas, mas, na verdade, reforçou o binarismo. O programa lançou ainda, em 30 de março de 2008, o quadro "Sexo Oposto" que, conforme texto do site, "mostrará com muito humor as diferenças entre homens e mulheres" . ${ }^{5}$ As seis edições do quadro mantiveram a mesma linha de abordagem feita pelo primeiro episódio intitulado "A Pré-história", que situou as diferenças, sobretudo, na biologia e na proximidade dos seres humanos com a natureza, incluindo os tempos pré-históricos. ${ }^{6}$ Vale ressaltar ainda que desde o sábado anterior ao lançamento do quadro até a véspera do último episódio, o jornal $O$ Globo publicou um informe publicitário em seu caderno principal, acompanhado de textos de pessoas envolvidas na produção do programa (artistas e diretores), professores e cientistas, que tratavam das diferenças sexuais e de gênero. O quadro também foi capa da Revista da TV (editada aos domingos e que divulga a programação televisiva da semana), desse mesmo jornal no domingo de sua estréia. $\mathrm{O}$ título da matéria era bastante emblemático para o que pretendemos discutir neste artigo: "A ciência explica".

Os exemplos são muitos e nos fazem pensar que o tema está na pauta do dia entre os/as jornalistas, cientistas e, podemos

5 www.globo.com/fantastico

${ }^{6}$ Em muitos momentos desse primeiro episódio, o texto pareceu ter sido retirado do Globo Repórter de 04 de maio de 2007, investigado neste artigo. O episódio está disponível no site do Programa. 
Cláudia Ribeiro e Fabíola Rohden

arriscar dizer, o público. Para Anne Fausto-Sterling (2000:117), referindo-se ao exemplo norte-americano, a mídia parece estar "preparada para acreditar que toda diferença social e psicológica poderia ser finalmente traçada pelas diferenças no formato do cérebro". As descobertas científicas sobre o cérebro chegam rapidamente à mídia, viram notícia e sua abordagem tende a levar-nos a concluir que as diferenças de gênero são biológicas e, sendo assim, imutáveis. Uma espécie de generalização dos destinos de homens e mulheres traçados pela natureza que exclui o social ou o minimiza assombrosamente.

Para desenvolver esse trabalho tomamos algumas referências dos campos da mídia, de gênero e da sexualidade. Sobretudo, analisaremos o tema apoiadas nas discussões empreendidas na contemporaneidade por estudiosas/os que vêm se empenhando para colocar em questão concepções que privilegiam o corpo biológico - hormônios, cromossomos, neurônios, genes, órgãos sexuais - na construção de gênero, buscando assim desconstruir a idéia de binarismo sexual. Esses mesmos estudos buscam esclarecer as estreitas relações entre essas idéias reducionistas e as ciências médicas que, ao longo de sua história, buscaram conferir estabilidade entre as categorias "homem" e "mulher", reforçando o modelo binário e a separação entre sexo e gênero.

\section{Algumas considerações sobre a mídia em geral e sobre o Globo Repórter em particular}

A mídia, esse

sistema cultural complexo que possui uma dimensão simbólica, que compreende a (re)construção, o armazenamento, reprodução e circulação de produtos repletos de sentidos, tanto para quem os produz como para os que consomem (Medrado, 2000:244), 
ganha novas dimensões nos tempos atuais a partir das modernas tecnologias de comunicação e informação, aumentando as possibilidades de circulação de discursos de toda ordem, com os quais interagimos. Veiculados em programas dos mais diversos formatos, esses discursos contribuem sobremaneira no reforço de novos temas, atores e interpretações sociais e culturais, o que tem impacto na conformação identitária dos indivíduos (Giddens, 1993; Thompson, 2002). Assim, em um mundo marcado por relações fluidas e pela alta reflexividade das identidades e das relações com os/as outros/as, a subjetividade vai se tecendo influenciada por representações simbólicas: Quem sou eu? Como posso me relacionar com o/a outro/a? Que papéis devo assumir na sociedade? Como e em que posso me modificar? São questões para as quais, ao longo da vida, os indivíduos buscam respostas, muitas vezes, oferecidas pela mídia (Ribeiro e Siqueira, 2007). Nas palavras de Bauman (2005), a mídia tornou-se uma fonte de matéria bruta que os leitores/espectadores usam para enfrentar a ambivalência de suas posições sociais.

Em sua análise da mídia, Thompson (2002) também sinaliza para as mudanças contemporâneas nas formas de se informar e formar provocadas pelas mídias. Segundo o autor, das interações face-a-face que prevaleciam anteriormente, na contemporaneidade as relações mediadas cada vez mais tornamse fontes privilegiadas de informação e de conteúdo simbólico, em detrimento das que nos chegam a partir das interações com as outras pessoas. O rompimento dos limites desse tipo de interação e a proliferação das fontes mediadas disponibilizam uma diversidade cada vez maior de comportamentos, atitudes e modos de viver mostrados e discutidos cotidianamente na televisão, em revistas, jornais e em sites da internet, nos colocando em contato com uma infinidade de modos de ser e estar no mundo, podendo alterar nossas formas de ser e estar no mundo. Para o autor, nos apoderamos das mensagens da mídia e rotineiramente as incorporamos às nossas próprias vidas, construindo uma compreensão sobre nós mesmos. 
Tomemos agora o caso específico da mídia televisiva e, mais especificamente, o Globo Repórter. Logo de início, podemos dizer que um programa só permanece por 35 anos no ar se tiver a credibilidade do público. Para Zanchetta (2004), não é simples equacionar os fatores que explicam a credibilidade de um telejornal, pois estão atrelados a questões subjetivas, culturais $e$ conjunturais. Mas pode-se dizer com certeza que para se manter $e$ ampliar seu público exige-se que "o veículo divulgue informações consideradas confiáveis e corretas por pessoas e comunidades que têm posicionamentos e expectativas diversos" (Id. ib.:12). A idéia então é atingir um público diverso e extenso que, em se tratando de um programa de canal aberto veiculado no horário noturno, é formado por telespectadores/as com características distintas de classe social, formação escolar, regionalismo, idade, sexo, etnia, etc. Essa conclusão nos leva ao que foi colocado por Bourdieu sobre um interessante aspecto dos programas televisivos:

quanto mais um órgão de imprensa ou meio de expressão qualquer pretende atingir um público extenso, mais ele deve perder sua aspereza, tudo que pode dividir, excluir (...), mais ele deve aplicar-se em não "chocar ninguém", como se diz, em jamais levantar problemas ou apenas problemas sem história (Bourdieu, 1997:63).

Constrói-se assim uma estratégia para agradar e veicular novidades, mas sem chocar o/a telespectador/a. No caso específico dessas edições do Globo Repórter, agradar pode significar não escapar ao que o público médio espera ouvir e ver, mas tendo o cuidado de levar algumas novidades a esse público, pois se trata de um programa jornalístico. Nesse sentido, ao tomar a biologia como detentora da "verdade" sobre as diferenças de gênero, o programa atendeu às expectativas de uma gama representativa da sociedade, inclusive os/as cientistas. E é a idéia de preponderância da natureza, ou da ordem natural, sobre a construção de gênero, que pretende não abalar. 
A ciência na mídia

Nesse mesmo trabalho, Bourdieu discute outras características da televisão que nos parecem bastante interessante para essa discussão. Segundo o teórico, há na TV uma "censura invisível" que atua sobre todos/as que nela estão. Uma autocensura percebida por poucos/as, mas que faz parte do jogo da televisão. No caso dos/as entrevistados/as, a censura se dá na seleção do tema e sua abordagem, no tempo disponível para a fala e sobre quem pode falar sobre determinado assunto. Mas foi para a censura imposta aos/às profissionais de televisão que Bourdieu chamou a nossa atenção. Segundo o autor, embora os/as jornalistas sejam ávidos por investigar denúncias e desvelar mecanismos de manipulação na sociedade, não fazem o mesmo trabalho com os meios de comunicação, se submetendo ao poder vigente, tornando-se conformistas e atuando na manutenção da ordem simbólica, muitas vezes sem se darem conta disso. $\mathrm{O}$ autor considera, portanto, que a televisão exerce uma forma particularmente perniciosa de violência simbólica devido ao seu poder de abrangência, inserção e convencimento, não apenas sobre os/as telespectadores, mas também sobre os/as que nela atuam, aspecto que podemos perceber claramente a partir da análise desses programas. ${ }^{7}$

Em se tratando de um programa jornalístico, a novidade, ou notícia, é primordial. No que diz respeito ao nosso tema, a novidade se fez presente de forma mais explícita no programa de 04 de maio, quando foi defendida e reforçada a idéia de inversão hierárquica entre o masculino e o feminino. No entanto, não foram anunciadas mudanças, ao contrário, a hierarquia foi reforçada alterando apenas a ordem dos fatores. Ao apontar nuances destoantes da ordem tradicional, como no caso da fragilidade masculina, optou-se pelo "politicamente correto", tendência que tem atravessado discussões sobre temas sensíveis

7 Nesse mesmo trabalho, Bourdieu (1997:22) define violência simbólica como "a que se exerce com a cumplicidade tácita dos que a sofrem e também, com freqüencia, dos que exercem, na medida em que uns e outros são inconcientes de exercê-la ou de sofrê-la". 
Cláudia Ribeiro e Fabíola Rohden

em nossa sociedade - etnia, raça, classe social, violência, gênero -, sobretudo na mídia. Procurou-se assim jogar novas cores sobre a questão, objetivando agradar, ou desagradar menos, aos/às que pudessem discordar, ou desconfiar, da abordagem biologicista.

A premissa da suposta neutralidade e da isenção, elementos importantes em um programa jornalístico, estão presentes quando se dá voz aos cidadãos e às cidadãs - especialistas e/ou pessoas "comuns". A notícia é construída, portanto, por diversas vozes e opiniões e não apenas pela do apresentador, o que pretende demonstrar que se trata de uma opinião surgida fora do meio, vinda da população. Claro que houve respostas que destoaram da linha imposta pelo repórter, mas foram em menor número. Além disso, no caso específico do primeiro programa, depois das falas de entrevistados/as que privilegiavam a cultura em detrimento da biologia, o repórter (narrador privilegiado que tem o poder de "costurar" falas, assuntos e enfatizar ou minimizar opiniões) retomava sua estratégia de fazer perguntas retóricas ao/à telespectador/a, levando o tema outra vez para a dicotomia entre feminino e masculino e para a preponderância das ciências biológicas. Mas é na própria escolha da Biologia como parâmetro de discussão dessas questões, e na escolha de laboratórios como cenários principais das entrevistas, que a idéia de neutralidade se faz mais presente.

A idéia de uma investigação detalhada, importante para a valorização desse tipo de programa, também esteve presente. É para transmitir essa idéia que os/as jornalistas dos dois programas (especialmente no primeiro), entrevistaram médicos/as e especialistas de diversas universidades e centros de pesquisas do eixo Rio de Janeiro-São Paulo-Brasília, estiveram em uma escola de ensino fundamental; visitaram hospitais e clínicas em diferentes estados brasileiros, foram às casas de algumas famílias e deram destaque à Fundação Oswaldo Cruz (Fiocruz). No caso da Fiocruz, sua importância é explicitada da seguinte forma pelo repórter no programa do dia quatro: "Como sexo é saúde, a 
A ciência na mídia

equipe do Globo Repórter procurou o mundialmente respeitado Instituto Oswaldo Cruz, no Rio de Janeiro".

Por fim, chamamos a atenção para o fato de que o primeiro programa é atravessado pelo tema "sexo", que muitas vezes chega a ser explicitado pelo repórter, embora esse não fosse seu tema. Isso não chega a ser uma novidade, haja vista que nos últimos anos essa vem sendo uma estratégia cada vez mais usada na mídia, sobretudo na televisão. Tomando o que coloca Foucault (1997) sobre instituições normativas da sociedade, pode-se dizer que a televisão vem se tornando instância de produção de saber, de poder e de discursos sobre sexo. Para esse autor, referindo-se à restrição da fala sobre sexo colocada em andamento a partir do século XVIII, o que se estabelece não é o silêncio, mas, ao contrário, uma incitação à fala promovida justamente pela idéia de sua restrição. "Não se fala menos de sexo, pelo contrário. Falase dele de outra maneira; são outras pessoas que falam, a partir de outros pontos de vista e para obter outros efeitos" (Foucault, 1997:30). O sexo deve ser falado como forma de controle - "falar de si", "confessar-se" - e falado dentro de certos parâmetros e por quem pode falar. $\mathrm{Ou}$, em suas palavras:

cumpre falar de sexo como uma coisa que não se deve simplesmente condenar ou tolerar, mas gerir, inserir em sistemas de utilidade, regular para o bem de todos, fazer funcionar segundo um padrão ótimo. O sexo não se julga apenas, administra-se. Sobreleva-se ao poder público; exige procedimentos de gestão; deve se assumido por discursos analíticos (Foucault, 1997:27).

Embora o sexo esteja implicitamente articulado ao tema do programa, o assunto é trazido de forma totalmente descontextualizada em vários momentos (ver site), levando-nos a crer que, diferentemente do que se possa pensar, não houve um silêncio sobre o sexo, mas uma incitação em "colocá-lo em discurso" que atravessou todo o programa e se mostrou mais explícito em alguns momentos. Um bom exemplo é a forma como 
o repórter busca falar de orgasmo durante uma entrevista que tinha como tema os "distúrbios do sono". Interessante notar que a entrevistada era uma neurologista especialista no segundo assunto com quem ele já havia conversado anteriormente sobre a insônia, o que nos levou a crer que seria esse o assunto a que voltaria num segundo momento da entrevista com ela. Vamos à conversa:

Repórter em off': Também no Instituto do Sono, em São Paulo, pesquisas são realizadas para esclarecer os mistérios e problemas do sono do homem e da mulher.

[Em seguida assistimos à conversa do repórter com a médica]

Médica: Em suma, isso é fisiológico, tem que respeitar não se sentir preterida nem rejeitada, é fisiológico, homem é diferente de mulher.

Repórter: Sempre após o orgasmo o homem pega no sono? Médica: Não sempre...

Repórter: Mas... [fala paralela à da médica]

Médica: Existem homens que têm insônia também [fala bastante enfática e reforçada com gestos] que tem um cérebro mais parecido com a mulher, a gente não sabe o que determina, é mais freqüente do que acontece com a mulher [corta para imagem desfocadas de corpos] com a mulher pode até ficar animada, dispersa.

A primeira fala da médica nos induz a pensar que ela estava concluindo uma reflexão, mas não sabemos exatamente sobre o que, embora se trate de uma especialista em distúrbios do sono. Por que, em nossa sociedade, uma mulher se sentiria preterida $e$ rejeitada por ter problema de sono? Sua fala parece mais adequada se pensarmos que se tratava de sexo e de mulheres que têm uma "disfunção sexual". Nossas considerações ancoram-se ainda na fala seguinte do repórter e no que ele diz imediatamente depois dessa entrevista: "Quando o assunto é sexo, haja fôlego -

8 Chamamos de off todo som (voz, ruído, música etc.) proferido sem que vejamos a fonte, ou o/a falante. 
A ciência na mídia

para a fantasia e a realidade. Sorte que a ciência é incansável, mostra que as aparências enganam - e muito!". Mas o tema que será tratado em seguida é o da docilidade dos gorilas machos, e o que foi tratado anteriormente não era sexo, mas insônia. Ou era sexo?

Podemos especular, portanto, que o repórter quis "apimentar" o programa em vários momentos tornando-o mais atrativo, como vem destacando Fischer $(2001,2002)$ em seus trabalhos sem, no entanto, entrar diretamente no assunto. Com relação ao tema deste artigo, a autora vai além e afirma que há uma pedagogia no sentido de construir uma

indissociável ligação entre o fato biológico e a condição de ser mulher, $e$ a idéia de que a feminilidade seria "dada" por um conjunto de características originadas da condição biológica, como a do 'mistério feminino' (relacionado basicamente à possibilidade de ser mãe) (Fischer, 2001:9596).

Para ela, a televisão tem uma participação decisiva na formação das pessoas e na própria constituição do sujeito contemporâneo tendo "uma íntima relação com a produção de modos de subjetivação na cultura" (Fischer, 2002:154). Além disso, a

televisão é parte integrante e fundamental de complexos processos de veiculação e de produção de significados, de sentidos, os quais por sua vez estão relacionados a modos de ser, modos de pensar, a modos de conhecer o mundo, de se relacionar com a vida (Id. ib.).

A televisão vem, portanto, desenvolvendo uma estratégia para afirmar-se como um lugar especial de educar e de promover a verdade, e a sexualidade tem sido tema recorrente dessa pedagogia televisiva, articulando de forma lúdica, mas não menos poderosa, saber e poder no que diz respeito ao tema. No caso desses programas, partimos do pressuposto de que operaram 
Cláudia Ribeiro e Fabíola Rohden

como uma pedagogia de ratificação das idéias essencialistas ao buscarem na natureza explicações para as diferenças entre homens e mulheres e para o amor materno, em detrimento dos aspectos sociais e culturais dessas construções. Essa opção reforça o binarismo entre os sexos, ratifica a idéia de que a abordagem biológica é a mais coerente e consolida a "obviedade" de que as identidades sexuais não escapam aos corpos, além de reafirmar a proximidade entre feminino e natureza e masculino e cultura.

\section{A preponderância das ciências biomédicas sobre as ciências sociais}

"Quem é mais forte, o homem ou a mulher? Você vai conhecer as últimas descobertas da ciência sobre as diferenças entre os sexos (...) Nossos cientistas prometem respostas para todas as perguntas".

A fala do apresentador Sérgio Chapelin, na abertura do programa de 04 de maio, é bem mais longa do que a transcrita acima", mas preservamos nesse trecho o "tom" que atravessou a abordagem desenvolvida no programa: a da diferença entre homens $e$ mulheres e da primazia das ciências biomédicas para compreendê-la.

Nas falas do repórter também não faltaram afirmativas ou perguntas retóricas que reforçavam a idéia de diferença $e$ a primazia das ciências:

Sono demais. Sono de menos. Quem sofre mais: eles ou elas? A ciência tenta descobrir usando cobaias.

[as cobaias são ratos e ratas em laboratórios]

$\mathrm{O}$ apetite é diferente entre homem e mulher? Quem come mais: ele ou ela? E quem engorda mais?.

[E a todo o momento dizia]

Afinal, somos mesmo diferentes?.

9 Ver site www.globo.com/globoreporter 
A ciência na mídia

[Ressaltando o poder das ciências biomédicas sobre o tema, foi enfático]

A guerra dos sexos já tem vencedor. Não foi o homem. Também não foi a mulher. A guerra dos sexos foi vencida pela ciência.

As diferenças foram localizadas nos corpos, reforçando a primazia das glândulas, hormônios, cromossomos, genes, natureza, privilegiando-se as ciências médicas como detentoras do saber $e$ da verdade sobre o tema, e colocando as ciências humanas na periferia dessa discussão. O gênero passou a ser uma construção da natureza, não da cultura.

Nossa afirmativa ancora-se ainda no fato de que na edição de 04 de maio, entre sete entrevistados/as, apenas duas eram da área das ciências humanas: uma pedagoga e uma socióloga. Os/as demais eram geneticistas, neurocientistas, neurologistas, endocrinologistas, biólogas e mesmo um primatologista. É relevante também salientar que, exceto o endocrinologista e a pediatra, entrevistados/as em seus consultórios, as/os demais foram entrevistados/as em laboratórios onde se pode ver diversos instrumentos de análise - microscópios, ampolas, tubos de ensaio, computadores -, confirmando a relevância para essa discussão da análise laboratorial, da tecnologia e, em última instância, da possibilidade de se provar em laboratório essas diferenças. $\mathrm{O}$ programa do dia 11 priorizou depoimentos de mães e, pessoas "comuns". Mesmo assim, foram entrevistados um ginecologista, um neurocirurgião e uma psiquiatra, além de mostrarem imagens de médicos e enfermeiras atuando em hospitais durante o parto, $e$ reificarem o poder da ciência, por exemplo, no caso da mãe que precisou fazer um exame de DNA para comprovar a maternidade de um filho que havia sido seqüestrado na maternidade. Como representante das ciências humanas, apenas uma psicóloga foi entrevistada.

No primeiro programa, é interessante salientar que a Fiocruz, que teve sua fachada mostrada em toda sua magnitude 
pelo repórter, foi escolhida como cenário para a entrevista com a socióloga, que conversou com o repórter em uma de suas bibliotecas. O que pode parecer contraditório é apenas o reforço do que se pretendia provar sobre a preeminência das ciências biomédicas sobre o tema, pois a socióloga fala de seus estudos ${ }^{10}$ dentro de um Instituto que, apesar de desenvolver relevantes pesquisas também na área das ciências sociais em saúde, é mais conhecido pelas pesquisas na área biomédica. Ao optar por uma biblioteca, mesmo dentro da Fiocruz, para entrevistar a socióloga, e laboratórios para os/as cientistas, o que pode ser visto como uma opção óbvia de cenário, na verdade parece esconder uma lógica que pode escapar até ao repórter, mas que nos pareceu clara: o alinhamento entre Ciências Sociais - biblioteca, livros / Ciência Médicas - laboratórios, tecnologia. Em uma sociedade que vem conferindo imenso valor às tecnologias em detrimento dos livros e da leitura, esse cenário acaba por valorizar ainda mais as ciências médicas.

A opção epistemológica pelas ciências biomédicas para a discussão dos temas da sexualidade e do gênero torna-se legítima na medida em que, a partir do século XIX, a medicina impõe-se como campo privilegiado para essas discussões ao configurar-se como a ciência capaz de fornecer explicações confiáveis, porque comprováveis através do exame dos corpos, sobre as diferenças entre homens e mulheres (Laqueur, 2001). Para Jordanova (1989), os conhecimentos e discursos produzidos pelos médicos estavam ( $e$ ainda estão) atravessados pelas questões de gênero e, apesar desses discursos não se destinarem a tratar dessas questões, mas das relacionadas ao sexo, eles se constituem, desde meados do século XVIII, como mediações sobre nossa compreensão acerca das relações de gênero. Se naquele momento não se conseguia ir além da superficialidade dos órgãos sexuais, ou dos esqueletos, tecidos e músculos para se encontrar as diferenças, os cientistas de

\footnotetext{
${ }^{10}$ Não foi explicitado o tema de sua pesquisa, mas sua fala foi sobre as diferentes
} formas de homens e mulheres lidarem com as mudanças trazidas pela velhice. 
A ciência na mídia

hoje, como os/as convocados/as pelo programa, vão aos genes, cromossomos, hormônios e, mais fortemente nos últimos tempos, às entranhas do cérebro na busca da ratificação da diferença. A ameaça de se borrar as fronteiras entre feminino e masculino foi o que levou os médicos de século XIX a se dedicarem às pesquisas sobre as diferenças. Esse mesmo receio pode estar estimulando as pesquisas atuais. O perigo ontem e hoje é desestabilizar a ordem de gênero, e a ciência acionada para proteger essa ordem ainda é a Biologia (Rohden, 2001).

É importante que se diga ainda que o mundo da ciência é historicamente compreendido como um espaço masculino, pois por muito tempo os homens foram considerados os únicos capazes de desenvolverem as aptidões necessárias ao desenvolvimento científico, como uma inteligência privilegiada, por exemplo. Essa ciência, atravessada como é pelas questões de gênero, tem poder político, um poder que é exercido

de maneira menos visível, menos conspícua (do que o poder do Estado ou institucional) e não sobre, mas através das estruturas institucionais dominantes, das prioridades, práticas e linguagem das ciências (Harding apud FaustoSterling, 2000:18).

\section{A primazia da natureza dos corpos sobre o gênero}

Ao abrir o segundo bloco do programa do dia quatro com a frase "Aprendendo com a natureza", o apresentador deixa claro que a natureza continuará a ser evocada para explicar as questões que levantará. Essa estratégia se desenvolve explicitamente a partir da busca de alinhamentos entre o comportamento de homens e mulheres contemporâneos em suas relações de casal $e$ pais, com os comportamentos de primatas e dos/as nossos/as ancestrais pré-históricos. Isso pode ser percebido na fala do repórter quando se refere aos orangotangos: "Macho dominador. Fêmea delicada. Alguns primatas parecem espelhar o comportamento da gente. Ou será que somos nós os espelhos 
Cláudia Ribeiro e Fabíola Rohden

deles?". O que se pretende é buscar na natureza traços de comportamentos humanos que nada têm a ver com o biológico, mas com a cultura. A estratégia de aproximação com os macacos conta com a opinião de um primatologista da Universidade de Brasília (UnB).

O mesmo acontece no programa do dia 11 , quando, já no primeiro bloco, a repórter dá o tom de como será tratado o tema falando do poder dos hormônios no surgimento do amor materno:

Alegria, medo e expectativa. O que passa na cabeça de uma mulher minutos antes de ela se tornar mãe? Parte da resposta está no cérebro. A explosão de sentimentos que acontece na hora do parto é resultado também de uma série de reações químicas fantásticas.

Continua na mesma linha ao falar de uma mulher que arriscou a vida para salvar o filho, sugerindo a existência de um instinto materno. E prossegue ao comparar mulheres e ratas de laboratório no quarto bloco do programa. Há uma ratificação da idéia de "natureza feminina" que produziria o desejo e o pendor incondicionais das mulheres para a maternidade, uma forma de aprisionar as mulheres nesse papel social, deixando de mostrar as mudanças sociais que as idéias de família e de maternidade vêm sofrendo nos últimos anos. ${ }^{11}$

Voltando ao primeiro programa, também no segundo bloco são convocadas pessoas "comuns" - pai e mãe - para falarem do comportamento de seus filhos, um menino e uma menina mais nova. Consideramos importante ressaltar que o pai é médico e a família é notoriamente de classe média. Aqui também há uma aproximação, se não com a natureza, com a idéia de "início" ou "pureza de comportamentos", pois se trata da infância. E isso fica

${ }^{11}$ Para uma discussão sobre a importância da maternidade e outros processos corporais na constituição da identidade feminina, considerando a força do discurso e prática médicos, ver E. Martin, 2006. Para o caso brasileiro, ver Rohden, 2001. 
A ciência na mídia

mais claro por ter sido esse assunto introduzido logo após o tema dos primatas. Interessante notar que foram o repórter e o pai, médico, que fizeram as colocações mais essencialistas sobre as diferenças. E que, embora a fala da mãe seja bastante pertinente, é a do pai que termina a entrevista.

Repórter em off: Apenas um ano de diferença entre eles. Mas, no comportamento, é bem aquela história: meninos são de um planeta e meninas de outro...

Mãe: Eles são diferentes em quase tudo.

Pai: Ele é bem diferente dela. Acho que é uma característica do sexo masculino. Ele quer se impor sobre todo mundo. A palavra e a opinião dele é que valem. É uma característica muito de macho. E quando tem amiga dela aqui, ele quer mandar, como o galo no terreiro.

Mãe: Não sou uma estudiosa da área, mas acredito que existam diferenças em função do sexo e também em função da cultura, da criação e do temperamento de cada um, da personalidade de cada um.

Pai: É aquela parte que a gente traz como homem, mas tem muito a ver com a educação, o exemplo dos pais.

Ao se nomear o sujeito como menino ou menina, o que vem acontecendo ainda no útero a partir de exames de ultra-som obstétrico $^{12}$, vai se construindo também o seu gênero instituindo assim essa realidade a partir da corporeidade. Essa verdade se ratifica e impõe através da história e se constrói sutilmente através

${ }^{12}$ Em trabalho recente, Chazan (2007) afirma que durante os exames de ultrasonografia fetal que acompanhou em sua pesquisa, a curiosidade por saber o sexo do feto, quando não explicitada pela gestante ou seu/sua acompanhante, era do/a profissional e, a partir da descoberta, dava-se início a um diálogo que consolidava a construção de gênero desse feto. Ao se referirem ao afeto do sexo masculino eram comuns comentários como: "é um meninão", "grandão", "vai ser um molecão". Enquanto que para os do sexo feminino ouvia-se com freqüencia que eram "agitadinha", "uma mocinha", "fofinha" ou "bochechudinha". 
Cláudia Ribeiro e Fabíola Rohden

de práticas, se estabelecendo antes mesmo do sexo, construindo uma "verdade" sobre o gênero. Garante-se, assim, a manutenção da heteronorma e a confirmação da hierarquização entre masculino e feminino (Butler, 2000:20-21).

Para Fausto-Sterling (2000:20-21),

a verdade sobre a sexualidade humana, devida aos estudiosos em geral $e$ aos biólogos em particular, são um componente de lutas morais, sociais e políticas travadas em nossas culturas e economias. Ao mesmo tempo, componentes de nossas lutas morais, sociais e políticas são, em termos literais, corporificados no nosso ser fisiológico.

Para a autora, a idéia de um cérebro diferente para homens e mulheres, que vem sendo propagada nos últimos tempos a partir do intenso investimento científico, acaba ditando regras para a educação diferenciada de meninos e meninas ou sobre a homossexualidade, além de ratificar crenças, por exemplo, a intuição feminina. Além disso, se tomarmos as diferenças sociais como resultados de anatomias diferentes, talvez induzidas por hormônios ainda durante a fase fetal, poderemos argumentar que não há sentido em desenvolver políticas sociais que busquem a equidade entre homens e mulheres em alguns campos como a engenharia ou a física, afinal, "não se pode tirar sangue de pedra" (Fausto-Sterling, 2000:118).

O depoimento da fonoaudióloga no primeiro programa é o mais flagrante quanto à arbitrariedade da fixação das diferenças de gênero unicamente nas diferenças dos corpos, e da implicação com a hierarquia de gênero implícita nessas diferenças, sobretudo porque seu comentário, em princípio, não guarda nenhuma relação com sua profissão, o que nos leva a pensar que a escolha por esse depoimento tinha a finalidade única de reforçar as diferenças. Segue a fala na íntegra: 
A ciência na mídia

Fonoaudióloga: Acredita-se que é mais fácil o homem ir à guerra porque, como ele tem o cérebro mais sistemático, classifica mais facilmente quem é o amigo e quem é o inimigo. A mulher, por ter um cérebro mais intuitivo, mais emocional, e por ter um cérebro mais empático, tem mais dificuldade nessa classificação.

No fim desse mesmo bloco, depois de mais uma pergunta do repórter sobre a existência ou não das diferenças, a pedagoga afirma que elas existem, mas que frisá-las, por exemplo, determinando o tipo de brincadeiras mais apropriadas para meninos e meninas, é prejudicial para a formação das crianças, pois as impede de ter outras vivências fundamentais para a vida adulta, além de ser uma estratégia de reafirmação da assimetria de gênero.

De toda forma, é notória a primazia do enfoque biomédico sobre a questão, seja pelo número de vezes em que a ênfase na cultura vem à pauta, pelo número de pesquisadores/as da área biomédica chamados a opinar, ou por privilegiar as imagens de laboratórios. O repórter cumpriu sua função de buscar opiniões diferentes para um mesmo fato, mas sua ênfase nos aspectos biológicos parece se enquadrar numa estratégia do telejornalismo que Bourdieu classificou como "ocultar mostrando", ou seja,

mostrar uma coisas diferente do que seria preciso mostrar caso se fizesse o que supostamente se faz, isto é, informar; ou ainda mostrando o que é preciso mostrar, mas de tal maneira que não é mostrado ou se torna insignificante, ou construindo-o de tal maneira que adquire um sentido que não corresponde absolutamente à realidade (Bourdieu, 1997:24).

Retornando a Laqueur (2001), a localização das diferenças nos corpos é uma tradição que começa a se estabelecer entre os séculos XVIII e XIX. Até então, prevalecia a teoria de Galeno sobre o sexo único que definia o corpo masculino como padrão e o 
feminino como seu oposto e invertido, interiorizado. A diferença se situava no grau de perfeição e no calor dos corpos, ou seja, a presença maior ou menor de calor expulsava os órgãos sexuais masculinos exteriorizando-os, enquanto o corpo feminino, mais frio, mantinha os órgãos internamente. A idéia de dois sexos incomensuráveis começa a se estabelecer nesse período com a virada epistemológica que passa da prevalência das explicações referendadas nas idéias religiosas, para o cartesianismo que coloca a razão como central na construção de conhecimento.

Ainda segundo o autor, o contexto político, modificado pela Revolução Francesa, influencia fortemente o campo de batalha dos gêneros, pois se a nova ordem defendia os princípios de igualdade, mulheres e homens deveriam estar no mesmo patamar, podendo desempenhar as mesmas funções sociais e políticas. Essa situação que colocaria a primazia masculina em questão e em perigo fez gerar outras explicações para manter a ordem hierárquica, e a medicina, que começava a despontar como ciência importante, vai fornecer os argumentos para a manutenção da ordem. Ao se localizar as diferenças nos corpos, as reivindicações femininas por igualdade perdem força sob a idéia de fragilidade física feminina comprovada em seus corpos, seus ciclos. A diferença não é mais de calor, mas está inscrita nos corpos: na anatomia, nos músculos, no esqueleto $e$, principalmente, no útero e nos ovários. O modelo do sexo único dá lugar ao traçado pela fisiologia e biologia que criam a idéia da bi-sexualidade original, e os órgãos, até então considerados os mesmos, mas invertidos, passam a ser vistos como tendo diferenças incomensuráveis. Para Sinding (2003), a pressão do biológico sobre o social passou também pela necessidade de se controlar a fome e as epidemias, buscando-se a saúde coletiva $e$ individual através de técnicas de controle e de transformação da vida humana .

No começo do século XX, as pesquisas sobre hormônios, ou extratos corporais, como eram chamados na época, são também atravessadas pela cultura, ratificando o que foi construído no 
século XIX, a idéia de bipolaridade. Os hormônios começam a se configurar como elementos fundamentais na construção do gênero a partir dessa mesma lógica bipolar. O hormônio feminino por excelência, a progesterona, conferiria à mulher os atributos da calma e da docilidade que têm forte ligação com a idéia de maternidade. E a testosterona, hormônio masculino, conferiria aos homens as qualidades da força, ímpeto, inclusive sexual, ou seja, da dominação (Sinding, 2003; Gaudillière, 2003; Lowy, 2003; Lowy e Rouch, 2003). As pesquisas, no entanto, apontavam para outro caminho, dissociando as "qualidades" masculinas e femininas das estruturas anatômicas fixas (Lowy e Rouch, 2003). O que se descobre na verdade é que o sexo biológico é composto de múltiplas características e diversos níveis - anatômico, psicológico, hormonal, celular, cromossômico, indo muito além dos hormônios. Isso começa a complicar a idéia de bipolaridade, possibilitando o surgimento de uma discussão levada a cabo por feministas a partir dos anos 1950 sobre os papéis femininos e masculinos fundados na biologia (Id. ib.).

Porém, mesmo com as descobertas da presença de hormônios femininos nos homens e masculinos nas mulheres, que demonstraria a existência de um contínuo entre os dois sexos e colocaria em questão as "qualidades" masculinas e femininas definidas pelas gônadas (estruturas anatômicas fixas que amparavam a dominação masculina $e$ os lugares sociais), essas crenças não se desfizeram, preferindo-se duvidar da orientação sexual das pessoas testadas nas pesquisas do que por em questão a idéia de bipolaridade (Sinding, 2003; Gaudillière, 2003; Lowy e Rouch, 2003). De toda forma, essas pesquisas e seus resultados possibilitaram o surgimento da idéia de dissolução entre sexo e gênero, levando estudiosas feministas a insistirem na historicidade do "sexo biológico" para dizer que as diferenças entre homens e mulheres não são naturais e nem imutáveis, mas dependem, entre outras coisas, dos conceitos e práticas científicas.

No primeiro programa o tema dos hormônios é tratado em um dos blocos - "Meninos e meninas" -, dando o tom da 
Cláudia Ribeiro e Fabíola Rohden

abordagem que seria escolhida para o tema. O bloco começa mostrando dois bebês num berçário de maternidade e afirma que aparentemente eles são iguais, mas "Pois é, as aparências enganam. Alguns cientistas acham que já nascemos com grandes diferenças - e não apenas nos órgãos sexuais". O repórter continua suas explicações sobre o tema afirmando que as diferenças são estabelecidas pelos hormônios secretados pelo cérebro ainda na barriga da mãe. Em seguida, dá voz ao neurocientista:

Repórter: Já dentro da barriga da mãe, as diferenças entre meninos e meninas seriam determinadas pelos hormônios sexuais, agindo no cérebro do futuro bebê.

Neurocientista: O efeito mais forte que se conhece é o da testosterona, que é o hormônio que os bebês masculinos produzem em grande quantidade no começo da vida, já durante a gestação. A testosterona atrasa ligeiramente o desenvolvimento do lado esquerdo do cérebro, que é o que está associado à fala. É uma explicação bastante razoável para o fato de as meninas começarem a falar mais cedo.

Um exemplo flagrante dessa inter-relação entre biologia, cultura e prerrogativa dos hormônios para arbitrar sobre comportamentos, pôde ser assistido nos minutos iniciais do programa de 11 de maio, a sexta-feira anterior ao dia das mães. Como já foi colocado, o programa defende a idéia de que esse amor seria provocado, ou estimulado, por um hormônio produzido no hipotálamo, uma região do cérebro que teria como função principal provocar as contrações, facilitando o parto. Mas o que a repórter destacou foi a relação entre esse hormônio e o amor materno, ou seja, além de provocar as contrações uterinas, esse hormônio provoca uma grande transformação no cérebro, como explicou o neurocientista da Universidade Federal do Rio Grande do Sul (UFRGS) entrevistado: 
A ciência na mídia

O cérebro diz para a mãe: olha, agora nós vamos fazer tudo aquilo que preparamos durante os nove meses. A criança está ali, portanto, agora é hora de apresentar os comportamentos que já foram preparados anteriormente durante a gestação. É o amor, o vínculo, a devoção pelo filho.

O papel da cultura é completamente descartado, ou silenciado, no que diz respeito à construção desse amor. E mesmo que isso seja levantado no bloco que trata de depressão pós-parto, por exemplo, é com essa ênfase na idéia de amor incondicional $e$ natural de uma mulher pelo seu/a filho/a que o programa se inicia. $\mathrm{Na}$ abertura são apresentadas ainda imagens de mulheres com seus/as filhos/as e frases ditas pela repórter ou pelas mães, que reforçam essa idéia:

Elas estão perdidas de amor

Ela é o amor da minha vida

Eu acho que é a melhor coisa que a mulher pode sentir

A gente ama, é intenso, incondicional, é forte. ${ }^{13}$

Em outro trecho desse mesmo programa voltamos aos laboratórios e ao mundo animal para buscar informações também sobre essa relação "tão forte" entre mães e filhos/as:

Há dez anos, pesquisadores do laboratório da UFRGS buscam determinar as bases do amor materno. Eles não desgrudam os olhos das ratinhas. Por serem mamíferos, com ovulação e variações hormonais semelhantes às das mulheres, as ratas também têm uma ligação muito forte com seus filhotes. Por isso, a relação deles serve para fazer um paralelo com a dos seres humanos.

${ }^{13}$ Esse trecho completo pode ser visto em um vídeo disponibilizado no site do programa. 
Cláudia Ribeiro e Fabíola Rohden

A comparação parece absurda, mas o tom da fala da repórter e a importância do programa conferem legitimidade a essas idéias.

\section{Fragilidade masculina: a novidade trazida pelo programa?}

O programa do dia 11 deixa transparecer a idéia de que as mulheres são seres bastante fortes física e emocionalmente: arriscam suas vidas para salvar os filhos da morte eminente, se submetem aos dolorosos e longos tratamentos médicos para engravidar, sofrem as angústias e dores do parto, lutam anos na justiça para reaverem filhos seqüestrados e são capazes de suportar e superar a morte de um filho, transformando a dor em ajuda ao próximo. Mas foi o programa do dia 04 que explicitou $e$ defendeu a idéia de que os homens são mais frágeis que as mulheres. A tese central do primeiro bloco foi a fragilidade do sexo masculino, quando se buscou em vários aspectos reverter a lógica da hierarquia masculina construída historicamente, mostrarse assim inovador. Para levar o/a telespectador/a a chegar a essa conclusão, a estratégia do programa foi reforçar a todo o tempo a bipolaridade entre os sexos.

Para se chegar ao objetivo de mostrar a "novidade", ou a fragilidade masculina, o repórter recorre a várias estratégias. Um bom exemplo é sua fala logo após o que diz o primatologista sobre o fato de serem os machos dos orangotangos mais carinhosos e cuidadosos que as fêmeas: "Falando de animais e humanos: será que existe mesmo o tal do sexo frágil? E qual é: o homem ou a mulher?" Em outro momento, também tomando os primatas como referencia, repete a mesma pergunta retórica sobre a fragilidade dos dois sexos: "A fêmea que domina o grupo. $\mathrm{O}$ macho que toma conta dos filhotes. Quem é o mais fraco e quem é o mais forte?". Ou ainda quando fala da fragilidade genérica masculina:

é muito mais comum o aborto natural de fetos masculinos do que femininos. Para cada 105 meninos que nascem, 
A ciência na mídia

quatro morrem antes do primeiro ano de vida. E essa mortalidade masculina continua, da juventude à velhice, a ponto de haver no Brasil mais 1,5 milhão de mulheres do que homens a partir dos 60 anos.

Mas como afirmar que meninos morrem mais se não apresenta os dados da mortalidade entre as meninas? Ele mostra, ainda, "ignorar" as pesquisas sobre a mortalidade entre jovens do sexo masculino em decorrência dos homicídios que vêm modificando a pirâmide populacional (Cano e Ferreira, 2003). Não faz menção também à etnia, localidade e classe social, fatores importantes para a obtenção desses dados. Ou seja, ele parece querer provar a tese da fragilidade masculina e para isso lança mão de argumentos extremamente mal construídos.

O interessante nisso é que o senso comum já reformulou a idéia de ser o homem o sexo forte em muitos aspectos, diferentemente do que afirma o repórter. Mas a diferença aqui são os argumentos usados para provar essa idéia. Enquanto as pessoas "comuns" apóiam-se na realidade para provar essa tese ou seja, o sexo feminino é o forte porque desempenha várias funções ao mesmo tempo, desenvolve uma dupla jornada de trabalho, menstrua todos os meses, dá à luz etc., -, o programa amparou-se nas ciências biológicas e na genética, reforçando a idéia de que é essa a ciência capaz de dar essas respostas. E ainda mostra o quanto o programa é moderno e empenhado em buscar o que há de mais inovador para informar os/as telespectadores/as, valorizando seu "produto". Ao final do primeiro bloco, o repórter reafirma sua tese a partir da fala desse mesmo geneticista:

Repórter: Então, quem é o sexo frágil, afinal?

Geneticista: De certa maneira, a idéia do sexo frágil vem do fato de que, provavelmente, são concebidos mais homens do que mulheres. A partir daí, para a gente é montanha abaixo em todas as etapas da vida - seja no pré-natal, no neonatal, na primeira infância, na adolescência ou na vida adulta, os homens morrem mais do que as mulheres. Até 
Cláudia Ribeiro e Fabíola Rohden

que chega ao ponto de, aos 90 anos de idade, no Brasil, termos dez mulheres para cada homem. Então, eu pergunto: Qual é o sexo frágil? Será que é o feminino? Não. É o que morre mais. E, no caso, é o masculino.

Como aponta Butler, gênero é sempre pensado como mutuamente exclusivo - não se pode ser homem e mulher,$- e$ hierárquico - estando os homens na posição de superioridade. No caso desse programa, o repórter tenta a todo o tempo levar o espectador a pensar, propõe algo novo ao inverter a hierarquia do masculino sobre o feminino. Mas, na verdade, ele não anuncia nenhuma mudança, ao contrário, reforça essa hierarquia, alterando apenas a ordem dos fatores. A idéia de rompimento com essa ordem hierárquica tradicional, que o repórter procura levar adiante durante todo o programa (especialmente no primeiro bloco) pode ser bem-sucedida aos olhos do/a telespectador/a desavisado/a, mas a idéia de relação binária e de uma hierarquia baseada na natureza dos corpos continua atravessando o discurso do repórter, que apenas muda os atores de lugar. É necessário lembrar que

os termos "masculino" $e$ "feminino" são notavelmente mutáveis; há histórias sociais para cada termo; seus significados mudam radicalmente dependendo de conexões geopolíticas e restrições culturais de quem está imaginando quem e para qual propósito (Butler, 2004:10 - nossa tradução).

\section{Considerações finais}

Apesar da presença de pesquisadoras das ciências sociais no programa de 04 de maio, que trataram as questões das diferenças de gênero a partir do ponto de vista sócio-cultural, é notória a busca pelas ciências biomédicas para elucidar dúvidas e comprovar a tese levantada pelo programa sobre a fragilidade masculina. Isso pode ser percebido facilmente nas falas do repórter proferidas depois de um desses discursos dissonantes. 
A ciência na mídia

Depois de cada uma dessas entrevistadas, ele voltou às explicações biológicas, aos laboratórios e consultórios, ratificando, também através das imagens, a importância da Biologia e da força da natureza sobre os corpos, comportamentos e desejos. No programa do dia 11, a presença de especialistas foi bastante reduzida se comparado ao anterior, e contou apenas com a participação de uma profissional das ciências sociais, uma psicóloga.

Esse exercício de recorrer também às ciências sociais para explicar as diferenças de gênero sem, no entanto, tomar realmente essa abordagem $e$ as construções sócio-culturais como verdadeiramente relevantes para essa questão, pode simplesmente servir para aplacar a necessidade surgida nos últimos anos de ser "politicamente correto", preocupação que tem atravessado também as discussões de questões igualmente sensíveis em nossa sociedade, como etnia, raça, pobreza e violência.

Se a mídia opera como uma pedagogia, ao privilegiar as ciências biológicas para essas discussões, provocou-se uma desvalorização e apagamento da importância das pesquisas na área social para essas questões junto ao seu público, o que corre paralelamente à supervalorização das ciências biomédicas, além da redução dessas questões à biologia. Além disso, retomando Bourdieu, sobre a televisão, a idéia é trazer o fato à discussão, mas sem chocar o público, uma "informação-ônibus", ou seja, "que não envolvem disputa, que não dividem, que formam consenso, que interessam a todo mundo, mas de um modo tal que não tocam em nada de importante" (Bourdieu,1997:23). Informações sem asperezas, homogêneas, "construindo-se o objeto de acordo com as categorias de percepção do receptor" e, além disso, que não levantam problemas, "ou apenas problemas sem história" (Id. ib.).

A questão não é só a ênfase nas ciências biológicas, mas o que isso implica: usá-las para reafirmar a diferença de gênero. A princípio, não haveria problema em constatar tais diferenças, mas o preocupante é que a construção social dessas clivagens opera 
Cláudia Ribeiro e Fabíola Rohden

sempre no sentido de reificar hierarquias pré-estabelecidas que circunscrevem o gênero. Mesmo trazendo a novidade da suposta fragilidade masculina, há poucas mudanças nesse sentido. Permanece uma verdadeira substancialização da diferença ao longo do tempo, embora o lócus vá variando. Se antes tínhamos a referência na anatomia e fisiologia, centrando a distinção em órgãos como úteros, ovários e testículos, agora o que prevalece é o moderno discurso em torno de genes e neurônios. Opera-se um processo de cristalização da diferença através da biologia. E a conseqüência suposta é de que se o fundamento é biológico, a distinção hierárquica seria imutável (Rohden, 2003). Podemos sugerir que, ao contrário dessa reificação da diferença usando o discurso biologizante, mais estimulante para a reflexão e frutífero para discussão sobre gênero atualmente seria analisar como historicamente são construídos temas mantidos sob o imperativo de uma natureza imutável $e$ definidora de corpos $e$ comportamentos.

\section{Referências bibliográficas}

BARROS Filho, Clóvis de. Ética na Comunicação: da informação ao receptor. São Paulo, Moderna, 2001.

BAUMAN, Z. Identidade. Rio de Janeiro, Jorge Zahar Editor, 2005.

BRUM, Juliana de. A Hipótese da Agenda Setting: estudos e perspectivas. Revista Razón y Palabra, out-nov, 2003. www.razonypalabra.org.mx.

BUTLER, J. Undoing gender. Routledge, New York/London, 2004.

CANO, I. e FERREIRA, C. E. Homicídios e evolução demográfica no Brasil: impacto da evolução demográfica na futura taxa de homicídios e a incidência dos homicídios na pirâmide populacional. In: HASENBALG, Carlos; SILVA, Nelson do Valle. (orgs.) Origens e destinos: desigualdades sociais ao longo da vida. Rio de Janeiro, Topbooks Editora, 2003.

CHAZAN, L K. "Meio quilo de gente": um estudo antropológico sobre ultra-som obstétrico. Rio de Janeiro, Editora Fiocruz, 2007. 
A ciência na mídia

FAUSTO-STERLING, A. Sexing the body. Gender politics and the construction of sexuality. New York, Basic Books, 2000.

FISCHER, R.M.Bueno. Televisão e Educação: fruir e pensar a TV. Belo Horizonte, Autêntica, 2001.

. O discurso pedagógico da mídia: modos de educar na (e pela) TV. Educação e Pesquisa, vol. 28, n 1, São Paulo, jan/jun. 2002.

FoucAult, M. Historia da Sexualidade: a vontade de saber. Rio de Janeiro, Edições Graal, 1997.

GAUDILLIÈRE, J-P. La fabrique moléculaire du genre: hormones sexuelles, industrie et médecine avant la pilule. In: La distinction entre sexe et genre: Une histoire entre biologie et culture. Cahiers du Genre, $n^{\circ} 34$, 2003.

GIDDENS, A. A transformação da intimidade. Sexualidade, amor \& Erotismo nas sociedades modernas. São Paulo, Editora da Universidade Estadual Paulista, 1993. [Tradução de Magda Lopes].

JORDANOVA, L. Sexual Visions: Images of gender in science and medicine between the Eighteenth and Twentieth centuries. Madison-WI, The University of Wisconsin Press, 1989.

LAQUEUR, T. Inventando o sexo: corpo e gênero dos gregos a Freud. Rio de Janeiro, Relume Dumará, 2001.

LOWY, I. Intersexe et transsexualités: les technologies de la medicine et la separation du sexe biologique du sexe social. In: La distinction entre sexe et genre: Une histoire entre biologie et culture. Cahiers $d u$ Genre, no 34, 2003.

LOWY, I. e RouCH, H. Genèse et development du genre: les sciences et les origins de la distinction entre sexe et genre. In: La distinction entre sexe et genre: Une histoire entre biologie et culture. Cahiers $d u$ Genre, n 34, 2003.

MARTIN, E. A mulher no corpo: uma análise cultural da reprodução. Rio de Janeiro, Garamond, 2006.

MEDRADO, B. Textos em cena: a mídia como prática discursiva. In: SPINK, Mary Jane. (org.) Práticas discursivas e produção de sentidos no cotidiano: aproximações teóricas e metodológicas. $2^{\mathrm{a} e d . ~ S a ̃ o ~ P a u l o, ~}$ Cortez, 2000. 
Cláudia Ribeiro e Fabíola Rohden

RIAL, C. Guerra de imagens e imagens da guerra: estupor e sacrifício na Guerra do Iraque. Revista Estudos Feministas, vol. 15 (1), Florianópolis, Universidade Federal de Santa Catarina, 2007.

RibeIRO, C $\mathrm{R}$ e SiqueIRA, $\mathrm{V} \mathrm{H} F$ de. O novo homem na mídia: resignificações por homens docentes. Revista Estudos Feministas, vol. 15 (1), Florianópolis, Universidade Federal de Santa Catarina, 2007.

ROHDEN, F. A construção da diferença sexual na medicina. Cadernos de Saúde Pública. vol.19, S2, Rio de Janeiro, Editora Fiocruz, 2003.

. Uma ciência da diferença: sexo e gênero na medicina da mulher. Rio de Janeiro, Editora Fiocruz, Coleção Antropologia e Saúde, 2001.

SINDING, C. Le sexe des hormones: lámbivalence fondatrice des hormones sexuelles. In: La distinction entre sexe et genre: une histoire entre biologie et culture. Cahiers du Genre, n 34, 2003.

THOMPSON, J B. A mídia e a modernidade: uma teoria social da mídia. Petrópolis - RJ, Vozes, 2002.

ZANCHETTA, J. Imprensa escrita e telejornal. São Paulo, UNESP, 2004. 